\title{
Forest resources of the Far East, their use and reproduction
}

\author{
Andrey Komin ${ }^{1,}$, Pavel Komin ${ }^{1}$, Vladimir Usov ${ }^{1}$, and Alexander Gridnev ${ }^{1}$ \\ ${ }^{1}$ Primorskaya State Academy of Agriculture, 44 Bluhera st., Ussuriisk, Russian Federation, 692510
}

\begin{abstract}
The paper provides an assessment of the state of forest resources in the Far Eastern Federal District and identifies the main factors affecting the qualitative state of forests. The reasons contributing to the increase in the area of forest fires are analyzed. One of the reasons contributing to the degradation of forest areas is also indicated - the accepted allowable cut, which does not always correspond to reality due to the use of outdated forest husbandry materials and its untimely implementation. Considering the issues of forest reproduction, an integrated approach is proposed for carrying out reforestation activities, including both the creation of forest plantations and the implementation of measures aimed at observing the technology of logging operations and preserving undergrowth. This will reduce the cost of reforestation work, as well as reduce the time required for the transfer of forest crops to a forested area. One of the conclusions is a change in the fundamental approaches to forest management in this area, taking into account the observance of environmental, economic and social requirements for forest management.
\end{abstract}

\section{Introduction}

One of the largest forest regions in Russia is the Far Eastern Federal District (FEFD), which covers an area of more than 6 million $\mathrm{km}^{2}$ and includes 10 subjects: Magadan Region, Chukotka Autonomous District, Sakhalin, Amur Regions, Primorsky, Khabarovsk, Kamchatka and Trans-Baikal Territories, Jewish Autonomous Region and the Republic of Sakha (Yakutia). The Far Eastern forests are distinguished by unique biodiversity. It is here that the main tracts of undeveloped and intact forests of Russia are concentrated.

The area of the forest fund in the Far Eastern Federal District (FEFD) is more than 532 million hectares, or about $48 \%$ of the forest lands of the Russian Federation. The area covered with forest vegetation accounts for 321 million hectares, $2 / 3$ of which is occupied by plantations with a predominance of conifers. The timber stock is more than 22 billion $\mathrm{m}^{3}$ (for coniferous farming, it exceeds 19.5 billion $\mathrm{m}^{3}$, for deciduous - about 2.9 billion $\mathrm{m}^{3}$ ). For the constituent entities of Russia located in the Far Eastern Federal District, timber reserves are distributed as follows $-44 \%$ are in the Republic of Sakha (Yakutia), $25 \%$ in the

* Corresponding author: lesfak11@mail.ru 
Khabarovsk Territory, 10\% each in the Amur Region and the Trans-Baikal Territory, 9\% Primorsky Territory, Kamchatka Territory - $5.9 \%$, Sakhalin Region - 3.1\%, Magadan Region $-2.1 \%$, less than one percent of the timber stock is concentrated in other regions (Table 1).

Table 1. Main indicators of the forest fund of the Far Eastern Federal District.

\begin{tabular}{|c|c|c|c|c|c|}
\hline \multirow{2}{*}{$\begin{array}{c}\text { Subjects } \\
\text { of the } \\
\text { FEFD }\end{array}$} & $\begin{array}{c}\text { Forest } \\
\text { area, } \\
\text { million } \\
\text { hectares }\end{array}$ & $\begin{array}{c}\text { Forested } \\
\text { lands, } \\
\text { million } \\
\text { hectares }\end{array}$ & $\begin{array}{c}\text { Stock of tree } \\
\text { plantations, } \\
\text { million cubic } \\
\text { meters }\end{array}$ & $\begin{array}{c}\text { Stock of mature } \\
\text { and overmature } \\
\text { tree plantations, } \\
\text { million } \mathrm{m}^{3}\end{array}$ & $\begin{array}{c}\text { Average } \\
\text { annual } \\
\text { growth, } \\
\mathrm{m}^{3} / \text { ha }\end{array}$ \\
\hline $\mathrm{RSY}^{*}$ & 254.8 & 156.7 & 8790 & 5190 & 0.6 \\
\hline $\mathrm{PT}^{*}$ & 11.9 & 11.5 & 1757 & 868 & 1.5 \\
\hline $\mathrm{KhT}^{*}$ & 73.7 & 51.3 & 5067 & 3101 & 1.1 \\
\hline $\mathrm{KT}^{*}$ & 44.2 & 18.7 & 1190 & 848 & 0.7 \\
\hline $\mathrm{ZT}^{*}$ & 32.6 & 28.2 & 2483 & 1145 & 0.8 \\
\hline $\mathrm{AR}^{*}$ & 30.5 & 22.9 & 2016 & 1028 & 1.3 \\
\hline $\mathrm{MR}^{*}$ & 44.7 & 16.8 & 430 & 268 & 0.3 \\
\hline $\mathrm{SR}^{*}$ & 6.9 & 5.7 & 622 & 313 & 1.4 \\
\hline $\mathrm{JAR}^{*}$ & 2.1 & 1.6 & 192 & 91 & 1.6 \\
\hline $\mathrm{ChAD}^{*}$ & 27.5 & 4.8 & 85 & 51 & 0.3 \\
\hline $\mathrm{Total}^{*}$ & $\mathbf{5 2 9 . 3}$ & $\mathbf{3 1 8 . 5}$ & $\mathbf{2 2 6 3 3}$ & $\mathbf{1 1 7 5 7}$ & $\mathbf{0 . 9 6}$ \\
\hline
\end{tabular}

${ }^{*}$ RSY - Republic of Sakha (Yakutia), PT - Primorsky Territory, KhT - Khabarovsk Territory, KK Kamchatka Territory, ZT - Zabaikalsky Territory, AR - Amur Region, MR - Magadan Region, SR Sakhalin Region, JAR - Jewish Autonomous Region, ChAD - Chukotka Autonomous District

\section{Materials and methods}

The research program provides for the analysis of reporting documents of the ministries and departments of forestry of the subjects of the Far Eastern Federal District, as well as conducting field audits at logging enterprises.

The forest cover of the Far Eastern Federal District is on average $48 \%$. The largest forest cover is observed in the Primorsky Territory - 78\%, the minimum - in the Chukotka Autonomous District - 6.8\%.

By designation, commercial forests prevail in the Far East - 56.5\%, protective forests occupy about $15.1 \%$ without the Chukotka Autonomous District, where all forests are classified as protective [1,8]. Reserve forests are identified only in four regions: the Republic of Sakha (Yakutia) - 50\% of the forest area, the Khabarovsk Territory $41 \%$, the Amur Region - 3\%, and the Kamchatka Territory - 63\%, mainly, these are low density and low-yield plantations growing on long-term frozen soils.

The productivity of the district's forests is low - plantations of IV-V quality classes prevail. The share of highly productive forests with a density of 0.8 and more, an operational reserve of $150-200 \mathrm{~m}^{3} /$ ha in the available forest fund does not exceed $20 \%$. 
Despite the high diversity of the forest fund, a large area of forested land, a huge timber reserves, the forests of the Far East are operationally quite unattractive. This is due to the complexity of natural conditions, socio-economic, functional and regulatory constraints.

First of all, this is the severity and mosaic nature of forest growth conditions, a dense hydrological network and high fishery significance of watercourses, deconcentration of industrially valuable timber reserves, a high proportion of endemics and rare species of flora and fauna, large reserves of low-grade timber and slow rates of formation of closed forest stands.

In addition, the region has long distances for the removal of timber from felling sites (on average, $90 \mathrm{~km}$ ), low concentrations of operational stocks of plantations. There is a high proportion of protective forests and specially protected areas, the parameters and sizes of cutting areas are limited, and strict requirements for the preservation of undergrowth, restrictions on intra-forestry transport and requirements for the preservation of biodiversity are determined [4].

The district is characterized by poorly developed infrastructure and expensive social services.

In general, forests available for exploitation occupy only about $40 \%$ of the forest fund area (Fig. 1). The rest are plantations on steep slopes, over $30^{\circ}(15 \%)$, reserved and protective forests $(15 \%)$, tundra and sub-tundra forests $(5 \%)$, and forests with a density of 0.4 and below $(25 \%)$.

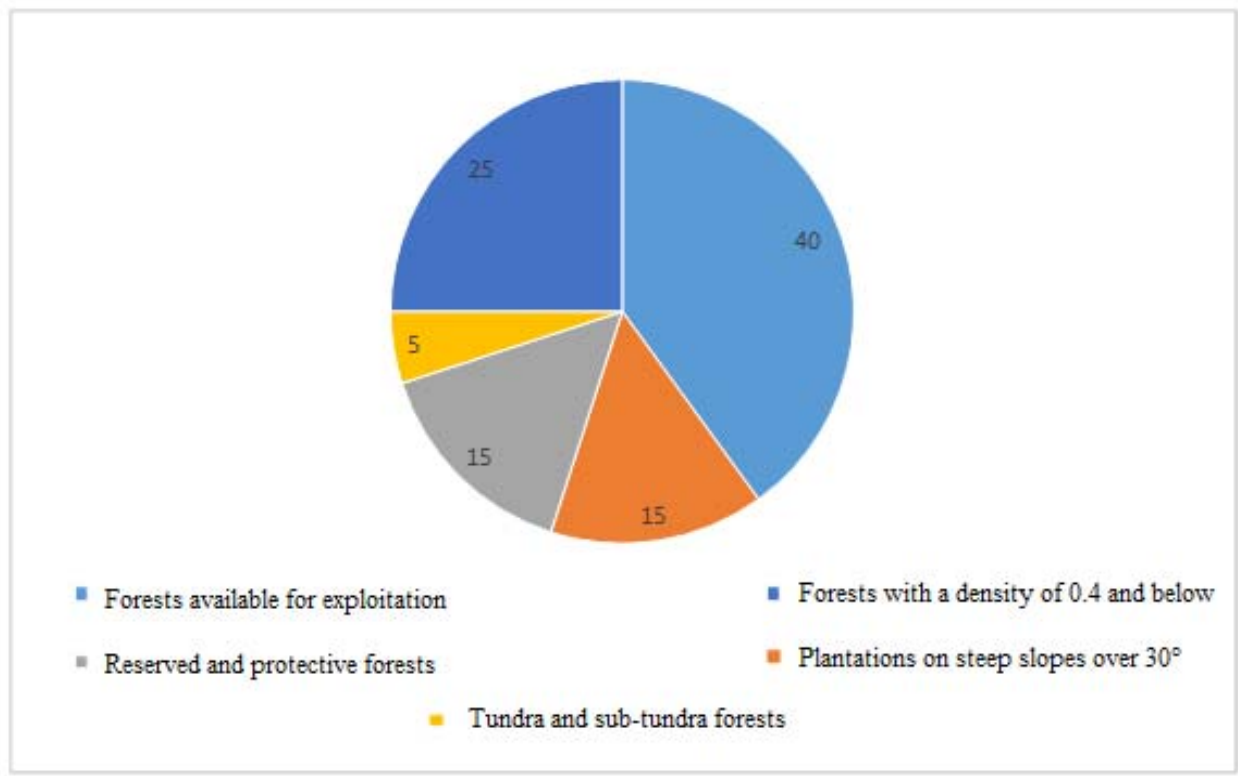

Fig. 1. Distribution of forests in the Far Eastern Federal District by silvicultural characters.

\section{Results}

Nowadays, there is a progressive depletion and deterioration of the quality of forest resources, a decrease in their nature conservation and ecological potential. This is especially noticeable in cedar-deciduous forests, which are completely removed from industrial use. As a result of conditionally clear and forced selective felling, their areas in the Khabarovsk Territory decreased by more than two times, in the Primorsky Territory they decreased by $12 \%$. Despite the adoption of prohibitive measures for felling in these types of forests, there is still a negative dynamic of the growth of their areas [2]. In the near future, a similar fate awaits spruce-fir and 
larch forests [3], which are being cut down everywhere and in a disorderly manner. According to the accounting data of the forest fund, over the past 20 years, the area of these forests has decreased by 20 and $11 \%$, respectively. In these forests, up to half of the plantations are occupied by disturbed and low-density forest stands [7].

The current situation is directly related to the management methods in the Far Eastern forests and the reforms carried out in the forest management structure in the last decade. At all stages of the formation and development of forestry in the region, the main task facing it was to provide high-quality forest resources for timber industry enterprises, which almost did not pay attention to improving the condition and reproduction of forests. The first place was given to the fulfillment of targets for timber harvesting. And, at present, despite the change of ownership in the forest industry, the picture of forest development has not changed. Cuttings are carried out almost as in the initial period of the settlement of the Far East, when the highest quality forest resources were removed. First of all, felling is assigned in places where productive forest stands are concentrated. Low-density and low-yield stands, as a rule, are not affected by felling due to the lack of processing capacity for low-market timber. The lower warehouse receives up to $80 \%$ of high quality timber, although its share in the plantings does not exceed $40 \%$. Consequently, loggers either cut down additional areas of the forest fund or significantly underestimate the stock of timber according to the materials of the coupe demarcation [1].

In addition, the main form of industrial exploitation of the Far Eastern forests is clear cutting (over 70\%), which is carried out not only under conditions of rational use, but also in plantations where such cutting is extremely undesirable or completely unacceptable. So, in uneven-aged spruce-fir forests, only $10 \%$ of clear cuts can be assigned, in fact, they are carried out on $70 \%$ of the area of spruce forests. A similar picture emerges during forest maintenance felling in mature and over-mature stands. Here, felling must ensure the required composition and quality of plantings, and enhance their useful functions. In practice, these cuts are the "worst option" of forced-selective felling, when only large-sized healthy wood of the most valuable coniferous and hardwood species is cut down in the cutting area [6]. Mainly doted conifers and low-value deciduous trees remain standing. This approach to felling leads to depletion of the forest fund, a significant decrease in the operational, protective and ecological significance of forests, as well as a decrease in biological diversity $[1,4,5]$.

In recent years, the accepted allowable cut, which is more than 80 million $\mathrm{m}^{3}$, also contributed to the degradation of the forest fund. When calculating it, along with undeveloped forest areas, all forest stands passed by felling without taking into account the frequency of recurrence are included in the calculation, which leads to an increase in the possible release of wood by 2-3 times [9]. In addition, in almost all subjects of the Far Eastern Federal District, more than $82 \%$ of forest areas have a forest hudbandry of over 10 years. The lack of accurate data on forest resources does not allow a full assessment of the state and quality of the forest fund in the region. According to expert estimates, the annual timber harvesting in the Far Eastern Federal District (taking into account the Trans-Baikal Territory) is 21-23 million, while the rate of development of the allowable cut is the lowest in the country and is $17 \%$.

Forest fires are also a consequence of unregulated felling, which are recorded on an area three times larger than the officially felling area. The most susceptible to fire are clearings and forest areas previously affected by fire. As statistics show, the area covered by forest fires in the first ten days of September 2020 in the country as a whole amounted to 14.96 million hectares, including covered with forest - 8.98 million hectares. More than $80 \%$ of active forest fires occur in the Far Eastern Federal District. The development of road infrastructure during the development of the forest fund leads to high accessibility of forest areas for the population, as a result, up to $85 \%$ of fires are man-made. Burned areas annually exceed 1.5 million hectares [2].

Of course, it is impossible to talk about the cessation or slowdown of reforestation processes and an increase in unforested land in the forest fund of the Far East. Despite the 
impact of various factors, the forest area in the Far Eastern Federal District, with a few exceptions, remains at the same level, and in some regions (Khabarovsk Territory, the Republic of Sakha (Yakutia) even increases [5]. However, the quality of reforestation in many cases does not meet forestry requirements. Data on the volume of reforestation activities in the Far Eastern Federal District are shown in Fig. 2.

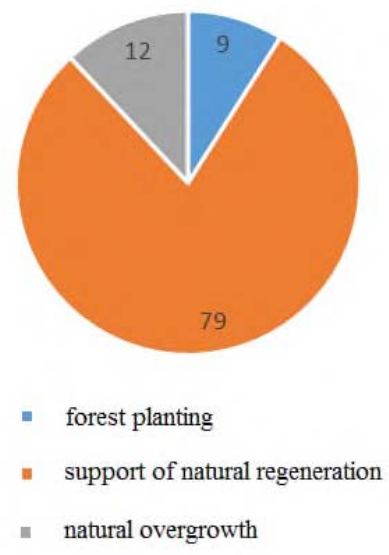

Fig. 2. Distribution of volumes of reforestation activities in the territory of the Far Eastern Federal District.

About $70 \%$ of clearings of coniferous plantations are reforested either with deciduous species or have a mixed composition with a predominance of birch and larch. The share of dark coniferous forests formed after felling accounts for no more than $10 \%$, light coniferous forests - about $40 \%$. Burns and burnt areas are also successfully reforested, but only in case of single fugitive ground fires. With repeated fires or repeated passage of fire through the territory, the regeneration of tree species is sharply reduced. In such areas, shrub and herbaceous vegetation becomes widespread, swamping of the area occurs in flat conditions, and the reforestation of indigenous forest stands stretches for tens and even hundreds of years. Most of the stands that have been cut by felling and fires are low-density and low-productivity forests of low-value and damaged trees, less often - prohibited for felling tree species.

\section{Conclusions}

The changes that have taken place in the forest fund under the influence of felling and fires require an immediate change in the forest management strategy in the region and the transition from extensive consumer forest use to sustainable forest use.

The solution to this problem, in our opinion, is possible in two ways. The first one is to switch to the widespread planting of forests in areas that are cut down and burnt-out, i.e. for the artificial cultivation of plantations. The second is sparing forest management, taking into account all silvicultural and environmental requirements, and highly effective protection of forests from fires and pests.

However, as practice shows, the first way - planting forest crops in the Far East is not always an effective measure of forest reproduction [5]. Statistical data indicate that more than half of the created forest plantations die in the first 5-10 years after planting. Taking into account that the main silvicultural areas in the region are felling and burning, which are necessarily burned out once every 7-10 years, the effect of forest planting in these conditions is extremely low. Moreover, artificial reforestation is a highly costly production associated with 
collecting seeds, growing standard planting material, planting seedlings mainly by hand, caring for them, and protecting them from pests and fires.

The second direction is associated with the natural reproduction of forests through preliminary and subsequent renewal. Studies show that with the correct organization of cutting operations, natural regeneration of $80 \%$ of the areas designated for felling can be ensured, which, in terms of growth intensity and productivity, is 20-30 years ahead of artificially created stands.

Of course, one should not completely abandon forest plantations. Forest plantations are needed in areas where natural regeneration does not occur and in areas intended for recreational purposes in the restoration of beautiful landscapes, as well as in the creation of plantations from fast-growing species for using wood as a raw material in the forest chemical industry.

Thus, the future of the Far Eastern forests largely depends on the chosen forest management system. It is the felling that should ensure the possibility of multi-purpose use and high-quality reproduction of forest resources, permanent coverage of felling areas with woody vegetation and minimization of the reforestation period. The main tool for performing one or another felling method is logging, the level of technical and technological compliance of which with silvicultural and ecological requirements for logging determines the area and dynamics of reforestation in the areas affected by felling, the possibility for plantings to perform protective functions, and the degree of forest fires.

\section{References}

1. A.N. Gridnev, S.V. Nifontov Analysis of monitoring results and forecast of the state of forest resources of the Khabarovsk Territory, Agrarian Bulletin of Primorye, 2, 42-45 (2017)

2. G.V. Gukov, T.V. Kostyrina, N.G. Razlomiy, On the conservation and integrated use of cedar-broad-leaved forests of Primorsky Territory Proceedings of the 4th International meeting "Conservation of forest genetic resources of Siberia", 46-48 (2015)

3. G.V. Gukov Larch and larch forests of the Russian Far East, 150 (2009)

4. A.E. Komin, P.A. Komin The role of agricultural science in the development of forestry and agriculture in the Far East Materials of the II National (All-Russian) scientific and practical conference, 245-252 (2018)

5. A. E. Komin Forests and forestry of the Russian Far East, Bulletin of the Irkutsk State Agricultural Academy, 54, 7-14 (2013)

6. D. Yu. Smirnov, A. G. Kabanets, B. D. Milakovsky, E. A. Lepeshkin, D. V. Sychikov Illegal felling in the Far East: world demand for timber and destruction of the Ussuri taiga: an overview, 39 (2013)

7. A.P. Kovalev The current state of the forests of the Russian Far East and the prospects for their use, 460 (2009)

8. V.N. UsovForestry complex of Primorsky Krai: achievements, problems, prospects Agrarian, Bulletin of Primorye: collection of scientific articles, 1, 40-45 (2014)

9. A.S. Sheingauz, V.P. Karjakin, V.A. Tyukalov Forestry complex of the Russian Far East, 62 (1996) 